\title{
Data Appendix
}

for

Regulation, Capital, and the Evolution of Organizational Form in U.S. Life Insurance

\author{
by \\ George Zanjani \\ Federal Reserve Bank of New York \\ 33 Liberty Street \\ New York, New York 10045 \\ Phone: 212-720-6320 \\ Email: George.Zanjani@ny.frb.org
}

The views expressed in this Data Appendix and in the referenced article are those of the author and do not necessarily represent the position of the Federal Reserve Bank of New York or the Federal Reserve System. 


\section{A Data Appendix}

The Data Appendix is organized as follows. Section A.1 discusses the sources and methodology behind the construction of the mutual market share and company count estimates presented in Figure 2, as well as a brief discussion of the history of fraternal and assessment market share. Section A.2 describes the sources, methodology, and definitions behind the company formation sample, and it also presents background information on non-legal reserve organizational forms. Section A.3 fills in details on the methodology behind the regulation and financial requirement data, and it also presents supplemental information on the time variation in regulation and financial requirements. Section A.4 offers details on sources for data on macroeconomic variables and post-1950 financial requirements, as well as additional details about how the latter evolved after the end of the sample period. Section A.5 presents various robustness tests, including alternative specifications of regulation variables and financial requirements, alternative sample definitions (e.g., including conversions and industrial/limited life companies), analysis of subsamples (startups, 1900-1924, and 1925-49), additional analysis of the form choices of reorganizers and converters, and, finally, a simple analysis of the association of regulation with entry. 


\section{A.1 Market Share \& Company Count Estimates}

Market share estimates are based on life insurance in force and are provided at 5-year intervals starting in 1850 and ending in 2000, with a few additional estimates: Specifically, estimates are provided for 1937 (the end of Stalson's analysis) and 1998 (the last year of company count data in the figure). In force amounts for 1850 through 1945 are constructed using Stalson [10] (Tables A and B), annual issues of Spectator Company's Life Insurance Year Book from 1900 to 1946 (henceforth referred to as "Spectator") and Spectator [8]. Stock and mutual companies were classified using information in Stalson's Tables A, E, F, and 15; the "Reports" section of Spectator; text references in Stalson and Knight [5]; insurance department reports (if available); and, as a last resort, whether or not the company was listed as having a capital stock (a term usually reserved for stock companies) in the "History" section of Spectator. Estimates for 1950 and forward were based on the stock/mutual split reported in American Council of Life Insurance (ACLI) [1].

The estimates exclude insurance underwritten by fraternal orders, assessment companies, and other institutions outside of the legal reserve market. However, these institutions (mostly through fraternal insurance) did hold 
significant market share circa 1900. According to Stalson's estimates in Appendix 25, fraternal and assessment insurance accounted for about $45 \%$ of the total insurance in force in 1900. This share declined rapidly in the 1910's, eventually dipping below $6 \%$ in 1937 - the end of Stalson's coverage. ACLI data can be used to construct market share estimates after 1937: It indicates fraternal share of $3 \%$ in 1950 and in the 1-2\% range starting in the 1960's through the modern day.

Data on companies in operation come from two sources. Stalson's Table A covers 1850 to 1937. The source for the post-1950 data is ACLI [1]. Post-1950 data is difficult to interpret because of the rising popularity of the "group" form of organization (in which multiple insurance companies belong to a similar parent). Subsidiaries in a group are typically organized as stock companies, so the proliferation of stock companies after 1950 owed partly to subsidiary formation. ACLI started classifying stock companies owned by mutual holding companies as "mutual" in 1999 (a year after the last data point in the figure), which coincided with a jump in the mutual count from 98 to 119. The decline in mutuality then resumed: By 2003, the number of active mutuals was 92. ACLI also changed its industry definition in 1994 to include companies specializing in A\&H insurance, which also caused a brief 
interruption in declining counts (the number of mutuals jumped from 108 in 1993 to 123 in 1994). Counts are provided at 5-year intervals from 1850 to 1995, with additional data points for 1937 (the end of Stalson's analysis) and 1998 (the year before the change in ACLI classification strategy), and no data points for 1940 and 1945 (the gap between Stalson's coverage and the ACLI coverage).

Both market share and company count estimates for the pre-1950 period cover the "legal reserve" life insurance market as implicitly defined in Spectator (Stalson's main source is also Spectator). Thus, fraternals, assessment companies, and other life insurance societies are excluded, as are small local industrial companies in various states. The post-1950 estimates rely on ACLI's definition, which also evidently excludes fraternals and other societies. The status of local industrial companies under ACLI's reporting could not be verified, but they seem unlikely to have had major impact on market share estimates.

\section{A.2 Company Formation Data}

The focus on formations (instead of market share) was driven by several considerations. As a practical matter, the data sources did not offer convenient 
aggregations of statistics by state: Using market share would have increased the data collection by more than an order of magnitude. Methodological considerations also favor the use of formations. Formations are likely to be more sensitive to the local regulatory environment than market share, which may be slow to respond to environmental changes because of the switching costs faced by both policyholders and companies. For companies, changing organizational form is a costly process, with years elapsing between initiation and completion. A final consideration is that conversions of national companies are difficult to interpret at the state level. For example, mutual market shares surged across the nation with the mutualizations of the 1910's, but the main regulatory pressure for conversion came from New York.

The focus on formations guides the choice of time period for study. $\mathrm{Mu}-$ tual formation was rare after the early 1950's, while pre-1900 data is relatively difficult to obtain and offers only a few dozen company formations. Accordingly, this paper studies an easily accessible period with many formations of both mutual and stock companies.

The primary data sources were the "Directory" and "Reports" sections in annual issues of Spectator, from 1900 to 1952, which contained comprehensive lists of the companies deemed to be legal reserve underwriters by 
Spectator. The type of company (mutual or stock) and the state and year of organization were noted. In cases where the organization year was not listed, the "year commenced" was taken as the organization year. Each formation was classified as either a "startup" or a "reorganization." A formation qualified as a reorganization if 1) an existing company reorganized or "qualified" to start underwriting business as a legal reserve company, or 2) a new company was formed for the purpose of reinsuring or taking over the business of an existing company. In both cases, the text of the Spectator report on the company (which indicated the "purpose" for which a company was formed) was used for classification. Annual issues of Best's Insurance Reports (henceforth referred to as "Best's") were used for 1912 and forward to confirm existence of companies and to supplement data where Spectator had missing or ambiguous information. In cases where the two sources disagreed on existence or form, reorganization status, or presented significantly different formation years, state insurance department reports were consulted where available.

The source material was remarkably consistent on categorizing companies as "stock" or "mutual." This consistency seems to derive not only from the statutory definitions used by the regulators, but also from ideas about 
ownership and control similar to those that permeate modern thinking about what distinguishes a stock company from a mutual company. In polar cases, categorization is straightforward: When investors controlled the company (through the Board of Directors) and claimed all of the profits as their own, the company was clearly a "stock" company; when there were no outside investors, and policyholders exerted at least nominal control (by electing the Board), the company was clearly "mutual." There are at least two common cases, however, that merit deeper examination. First, it was common for companies controlled by investors to share profits with policyholders via "participating" insurance contracts. These companies were classified as "stock" companies by the states and the trade publications, and this assignment seems sensible: Despite sharing in the profits, the policyholders in such companies typically exerted no direct control over the Board, and the extent of sharing was typically at the discretion of the company. Second, some of the early mutuals had a "guarantee fund" or "guarantee capital" consisting of subordinated debt issued to investors; however, unlike the surplus notes issued today, it was not uncommon for control rights (in the form of electing a fraction of the Board of Directors) to be attached to this debt. These companies were classified as "mutual," and the assignment fits because 1) the 
maximum annual interest on the guarantee capital was set by charter and 2) the guarantee capital was often retired at a later date, once the mutual had matured.

\section{A.2.1 Definition of a Life Insurance Company}

As noted in the text, legal reserve companies are usually defined as those operating under state laws that specify a minimum basis for reserve calculation. This definition is problematic on several levels. First, a company domiciled in a state without a valuation law in place would not seem to fit the definition. Second, laws governing fraternal insurers and other "alternative" institutions changed over the course of the 20th century: For example, by 1950, most state laws required valuations of fraternal insurers, which would seem to bring them within the purview of the "legal reserve" definition. Finally, some states allowed "industrial" or "limited capital stock" companies that were subject to valuation laws in some cases, but typically had restricted powers (e.g., limitations on the size of contract that could be issued) and lighter regulations (e.g., lower initial asset requirements).

By choice of source material, this paper follows the implicit definition of "legal reserve life insurance company" used by the rating agencies, which, to 
a large degree, follows conventions in insurance department reports. The reports typically had a standard "life insurance company" classification, and then had special names for other companies (see below). In cases where the standard "life insurance company" was operating under a legal reserve law, the agencies typically covered all complying life insurance companies except those with restricted powers due to having a reduced capital stock (known in various states as industrial companies, limited life companies, or limited capital stock companies). In those states without a legal reserve law, the rating agencies either followed the classification of the domiciliary state, or they may have used their own judgment or the judgments of other states where a given company was licensed. As will be discussed in more detail below, different statutory classes of companies, including stipulated premium companies, fraternal life insurers, assessment associations, mutual benefit associations, burial societies, and the like, usually received separate treatment - regardless of whether a valuation law applied to them or not.

The sample includes only "legal reserve" companies - not in the sense of the technical definition, but in the sense outlined above. That is, the sample includes companies referred to as "legal reserve" by the rating agenciesa reference usually reserved for those companies with the highest level of 
underwriting authority. Companies outside this definition came in a variety of forms defined by statutes. While the particulars varied from state to state, some generalizations are provided below:

1. Fraternal orders - Kip [4] notes several key characteristics of the statutory definition of the fraternal insurance society. First, there was a "non-profit" provision requiring the society to be organized solely for the benefit of its members. Second, the typical definition required the society to be organized on the "lodge system." Third, the society was required to have a "representative form of government." Most fraternals applied assessment insurance principles initially, but many migrated to "legal reserve" practices over time. Fraternals were virtually unregulated in 1900, but this changed in the early decades of the 20th century as solvency regulations were applied through sections of state insurance codes dealing explicitly with fraternal insurance.

2. Assessment companies The glossary of the Insurance Industry Handbook of the Internal Revenue Manual (posted at the URL http://www.irs.gov/irm/part4/ch37s06.html, viewed on June 7, 2005) defines assessment companies as "[c]ompanies selling to groups with similar interest such as church denominations or professional groups. Some assessment companies also sell directly to individuals of the general public. Such companies may or may not collect premiums; however, if funds are not sufficient to pay claims, then assessments may be made against members." These companies could be for-profit or nonprofit in nature, although assessment insurance was generally allowed only in highly restricted circumstances by 1950 .

3. Mutual benefit associations, mutual protective associations The IRS source defines mutual benefit associations as "[c]ompanies operating on the cooperative or assessment plan to pay individual losses." States often exempted these and similar associations from most regulations, but required them to have a "benevolent" character with respect to serving their membership. These associations are thus distinguished from for-profit assessment companies. Further, statutes often linked exemption from the general insurance law to a limitation on contract sizes. 
4. Stipulated premium companies The IRS source defines a stipulated premium company as a "hybrid organization possessing some of the characteristics of a legal reserve company and some of an assessment association." These companies typically collected premiums in advance but retained the right to assess policyholders. Premiums in theory represented actuarially appropriate premiums, and the minimum levels were sometimes specified by statute. The companies held reserves but were typically not held to the same regulatory standards as legal reserve companies.

5. Industrial companies Stalson (p. 462) notes key characteristics of industrial insurance that include a) small contract sizes, b) a "houseto-house, person-to-person" soliciting effort, and c) weekly or monthly collection of premiums in person by the agent. Industrial insurance was provided by many of the major underwriters, as well as by smaller specialist companies. Many states did not have special incorporation requirements for industrial companies, but some did. Such statutes defined industrial companies according to a limited contract size, the weekly or monthly premium collections, and sometimes simply by reference to the word "industrial." Industrial companies as defined by statute were subject to the other features of the "legal reserve" lawincluding valuation and reporting - in some states; others enjoyed relaxed regulation in areas other than the initial financial requirements (which also could be relaxed).

6. Limited capital stock companies / limited life companies A cousin of the industrial company, most frequently seen in Texas, was the "limited" company that was incorporated with less paid-in capital than required for regular companies. These companies could only issue contracts of limited size.

In some cases, the rating agencies drew sharp distinctions between the "legal reserve" forms and the form in question. Fraternals were treated separately from legal reserve companies by the rating agencies (regardless of operating methods). Assessment firms and benefit associations also received 
separate coverage, to the extent that they received any coverage.

Classification was less straightforward for companies in the last three categories, which sometimes received coverage from Spectator but rarely from Best's. In most cases, it seems likely that Spectator did not have a guiding rationale for inclusion and was thus inconsistent in its classification scheme. The two agencies typically matched each other and state insurance department reports when it came to "legal reserve" companies, but, when the odd stipulated premium company or industrial company appeared in Spectator, it often had many relatives judged to be similar by the state that did not appear. Limited capital stock companies in Texas (which could be formed with as little as $\$ 25,000$ in capital, instead of the $\$ 100,000$ required of fully empowered companies) are a unique case, in that Spectator consistently covered these companies and classified them as "legal reserve," while Best's consistently did not.

An earlier version of this paper relied entirely on Spectator's classification scheme, while the current version eliminates companies in the enumerated categories above that did not eventually achieve full legal reserve status. Companies that did achieve such status were treated as reorganizers.

Conversions (mutualizations and demutualizations) are also eliminated 
from the main sample. Conversions were defined in a manner similar to reorganizations. That is, a conversion is defined either as a reorganization of an existing company or as the forming of a new company to reinsure the business of the old company, where 1) the old and new entities are both legal reserve companies, and 2) the form of the new entity differs from that of the old. In the earlier version of the paper, the new companies formed during "reinsurance" conversions were treated as new formations.

Table A breaks down the full sample, including those observations eliminated from the main sample according to the logic above. The consequences of altering the sample definitions, as well as the formation patterns among different types of reorganizers within that subsample, are discussed in the robustness test section below.

\section{A.3 Regulation \& Financial Requirement Data}

Statute compilations and session laws for the mainland states and D.C. were used to identify enactment dates of insurance laws that applied to legal reserve companies formed during the sample period. Some qualifications are necessary. Although the data collection exercise is straightforward on paper, insurance codes of this period lacked clarity and were littered with conflicting 
provisions. Discretion was sometimes applied in determining which statutes applied to legal reserve companies. Moreover, some laws may have been missed. Unless compilation or session law indices indicated otherwise, only the insurance code was consulted. Thus, relevant laws buried in the general corporate or criminal codes may have been overlooked. The same can be said of laws that were enacted and quickly repealed within the five decade period, since not all of the session laws were reviewed. We attempted to get coverage for every state-year combination with a company formation and nearly achieved this goal: Only four formations were eliminated from the sample due to incomplete data on regulations or financial requirements.

Armstrong reforms were labelled as such (see Table 1) based on whether the Armstrong Committee recommended the regulation in its report. It is worth noting that not all of the reforms were innovations. For example, the Committee endorsed periodic valuations of insurance companies, but such provisions were common to state insurance codes before 1905 - although not all were applied with the rigor envisioned by the Committee.

We attempted to cast as wide a net as possible in identifying relevant statutes, but it should be noted that practical issues restricted the focus to laws that were easily characterized and verified. This restriction did remove 
texture in some circumstances, where simple characterization and verification proved elusive. For example, it would be desirable to have variables characterizing the nature of investment restrictions or voting procedures for mutual companies, but neither was obtained.

As noted in the main body, financial requirement laws typically stipulated minimum assets, deposits, or capital/surplus. However, some states also required mutual companies to collect applications for a minimum total face value of insurance and at least one annual premium (or a fraction thereof) from each consumer before starting business. In cases where this regulation was not subsumed by the financial requirement, it was converted into an asset requirement by using a premium rate of .04 times the minimum face value of insurance required times the fraction of the annual premium that had to be collected. The rate approximates the ratio of premiums to insurance in force, which was typically in the .03 to .04 range during the sample period.

It should be noted that the preceding characterization of financial requirements, which forms the foundation of the tests in the paper and Data Appendix, abstracts from some details. For example, deposit requirements - which required a company to deliver securities of sufficient worth to an administrator (typically an insurance commissioner), to be held in trust for the benefit 
of the policyholders - varied across states in terms of administrative details (e.g., responsibilities of the insurance commissioner with respect to monitoring the value of the deposit) and in terms of what types of securities were acceptable. Capital requirements also varied across states in terms of timing: While most states required capital to be fully paid in, some states allowed companies to commence business with a fraction (e.g., 50\%) paid in-with the remainder due some time later.

For the regressions, the financial requirements are converted into real figures (expressed in millions of 2002 dollars), using the consumer price index (Series E 135, All Items) from the Bureau of the Census [11] for the annual averages of 1900-1949, with the September, 2002 value of the ongoing index from the Bureau of Labor Statistics used as the reference point.

\section{A.3.1 Variation in Regulations over Time}

The Armstrong Investigation of 1905 signaled the beginning of a major reform movement, with many states adopting reforms over the next decades. Table B shows an expanded timeline of adoptions. Table $\mathrm{C}$ shows widespread positive sample correlation across regulations, suggesting that it is easier to identify effects associated with variables based on regulatory aggregates than ones 
based on individual regulations.

Table D provides details on the states that had financial requirement "regime changes" - in the sense of switching from a regime where the mutual requirement was less than the stock requirement ("favoritism") to one where the requirements were equal, or vice versa. In aggregate, the evidence points to significant differences in form use under different regimes. However, there are few states with a large volume of company formations both before and after a regime change. As a result, it is not surprising that the empirical estimates are less dramatic in the fixed effects setting.

\section{A.4 Miscellaneous Data}

\section{A.4.1 Macroeconomic Variables}

The real interest rate data are taken from the Bureau of the Census [11]. The real interest rate is a long-term rate calculated as the basic yield on 10-year high-grade corporate bonds (Series X 487-91) adjusted for the previous year's consumer price inflation (Series E 135, All Items). Other macroeconomic variables, including nominal and real GNP growth, inflation, unemployment, and alternative interest rate measures were also pulled from different tables in the same source and were used in robustness tests to be described below. 


\section{A.4.2 Financial Requirements after 1950}

Financial requirements for 1974 are from Carter [3]. The two states in 1974 that were judged to have requirements comparable to those of the mutual "hotbeds" of 1900-1949 (in the sense of having requirements amounting to $\$ 25,000$ or less in 1900 dollars for mutuals, and something substantially higher for stocks) were North Dakota (\$10,000 surplus for mutuals, $\$ 225,000$ capital and surplus for stocks) and North Carolina (\$100,000 for mutuals, $\$ 600,000$ for stocks). The population-weighted average (median) financial requirement for newly incorporated mutuals rose by about $88 \%(119 \%)$ in real terms between 1945 and 1974; the figures for stock firms were about $156 \%(155 \%)$. These figures understate the true impact of the changes, since all requirements in 1974 were capital and surplus requirements, while some requirements in the 1940's were still in terms of assets, deposits, or premiums.

The paper does not attempt to explain why some states adopted financial requirement differentials while others did not, nor what motivated those with differentials to get rid of them in the 1940's and 1950's. Though systematic treatment of these issues is beyond the ambition of the paper, the particular case of Texas - which accounted for more than a quarter of the mutuals in the sample - is suggestive. By the 1950's, in the words of McCandless [6] 
(p. 33):

[T] he state was still trying to "grow" its domestic insurers. Texas laws were meant to encourage the formation of insurance companies, not to make it more difficult. As the postwar economy gradually picked up steam, however, capitalization laws that were adequate during the 1930s quickly became outmoded, leading to a situation in which it was, plainly speaking, too easy to form and obtain regulatory approval of an insurance company. Scores of new companies sprang to life - some with little or no financial security. ... As might be expected, the whole structure started to unravel not long afterward.

Texas was rocked by a series of insurance scandals in the 1950's, and the revision of capital requirements in the 1950's appears to have been part of the legislative response aimed at reforming the industry. By raising requirements and eliminating differentials in 1956, the legislature reversed a policy that had been in place since 1909 .

Current financial requirements can be found in the National Association of Insurance Commissioners' Compendium of State Laws on Insurance Topics. By 1999, only 4 states made any distinction at all between the requirements for stock and mutual companies, and the number with requirements comparable to the "hotbeds" (in the sense described above) remained at two. 


\section{A.5 Robustness Tests \& Other Analysis}

\section{A.5.1 Alternative Models and Specifications}

The main body of the paper uses a pooled logit model and a conditional

fixed effects logit model for the empirical work. Alternatively, a random effects logit model could have been used. This model yielded results similar to those obtained from the pooled model, with the noteworthy exceptions being that the coefficient estimates for "Regulate" and "Reorganization" are larger in magnitude and meet the usual standards for statistical significance in all specifications.

In addition to exploring different models, we also considered different variables and sample definitions. Table $\mathrm{E}$ describes some additional regulation and financial requirement variables and presents descriptive statistics. These variables are used in some of the regressions discussed below.

Regulation Identification of the empirical association between regulation and mutuality is challenging. As noted above, the high correlation among regulations makes it difficult to estimate individual effects with confidence.

The regressions in Table 5 use the "Regulate" variable, and the positive coefficient reflects an association of mutuality with states that ranked as 
the most aggressive insurance regulators. The threshold of 13 laws used in the main body of the paper is evidently arbitrary, but the positive sign of the association was generally robust to changes in variable specification. However, the statistical significance of the association (which was generally confined to the fixed effects models of Table 5) was not. For example, when the threshold for "Regulate" is set at 10 or 11 laws instead of 12 or 13 , statistical significance is sacrificed, and the point estimates indicate a more modest association between mutuality and regulation in the fixed effects specifications. These lower thresholds correspond to a moderate regulatory standard - met or exceeded for $51 \%$ and $46 \%$ of formations, respectively; while thresholds of 12 and 13 were met or exceeded for $34 \%$ and $27 \%$ of formations, respectively. A threshold of 14 was met in only $3 \%$ of the cases and 3 states.

Table $\mathrm{F}$ presents regressions with some alternative regulation variables. The first, "Armstrong," was used in an earlier version of the paper to capture major enactments of regulation: It indicates states which have enacted at least three Armstrong reforms subsequent to 1905. Three other variables are introduced (see Table E) to indicate strength in three different dimensions of regulation - the basic regulatory apparatus, regulation of contract 
forms, and restrictions on management. The estimates are representative of the general pattern in empirical testing of the association between mutuality and regulation - the overall association between regulation and mutuality tended, if anything, to be positive; however, the usual standards for statistical significance were not always met, and findings on individual laws or subgroups of laws were not generally stable in the sense of being robust to specification changes or to moving from pooled to fixed effects estimation.

As a final illustration, Table G presents the results of regressions with an expanded set of regulatory explanatory variables. Although the financial requirement variables still register strong effects, most of the other coefficient estimates do not meet the usual standards for statistical significance.

Financial Requirements The main body of the paper uses variables that greatly simplify financial requirements by ignoring the distinction between capital requirements and asset requirements. Table $\mathrm{H}$ presents regression results based on logit models like those in the main body, except that financial requirements are now represented by capital and surplus requirements rather than asset requirements. In addition to the capital and surplus requirements for stocks and for mutuals, a variable for mutual asset requirements (other 
than surplus) is included. This inclusion recognizes that a number of mutual financial requirements were specified in terms of deposits or assets (rather than surplus), while stock financial requirements were typically capital and surplus requirements. Indeed, the stock capital and surplus requirement was equivalent to the stock asset requirement for nearly $95 \%$ of the observations, but this was true for the mutual analogs in only $67 \%$ of the observations.

The results are qualitatively similar to the ones presented in the main body. The pooled logit specifications do not indicate a noticeable difference between mutual capital and surplus requirements and mutual asset requirements, although the fixed effects specifications do suggest that the former may have been more important than the latter for startups.

Time Dummies and Macroeconomic Variables Using 5-year time dummies (instead of decadal dummies) did not materially change the key findings. The point estimates on the time dummies themselves indicate the 1930-34 and 1935-39 periods as having the strongest association with the mutual form, although the estimates do not consistently meet the usual standards for statistical significance.

The paper uses a real interest rate based on the 10-year basic yield of 
corporate bonds, but other macroeconomic variables from data in Bureau of the Census [11] were tested - with mixed results. In particular, shorter term rates (based on commercial paper) yielded similar results. Consumer price inflation exhibited a strong negative association with mutuality, and unemployment exhibited a strong positive association with mutuality. GNP growth did not yield statistically significant results. The inflation and interest rate variables yielded a fairly stable association with mutuality across the 1900-1924 and 1925-49 subsamples, while unemployment did not. Stock price variables, such as the dividend-to-price ratio and the price-to-earnings ratio, did not yield robust and statistically significant associations with mutuality.

Credit spreads (based on the difference between Moody's Baa and Aaa corporate rates, available 1919 and forward) yielded a very strong association with mutuality over the 1919-1949 period.

\section{A.5.2 Alternative Sample Definitions \& Subsample Analysis}

Including conversions (demutualizations and mutualizations) along with reorganizations adds 69 observations to the sample (see Table A). Running the models on this expanded sample results in a few changes worth noting.

xxiv 
First, the association of fraternal regulation with the stock form among reorganizers (indicated by a negative and statistically significant coefficient on "RD*Fraternal") becomes statistically weaker. Second, in the fixed effects specifications, the association of startup mutuality with strong regulation becomes smaller in magnitude and statistically weaker, while the association of startup mutuality with financial requirements becomes larger in magnitude and statistically stronger. This may derive from the fact that three states that had been dropped from the fixed effects estimation in the original sample are now included due to having at least one mutual formation (in the form of a mutualization).

Expanding the sample further by counting industrial and limited capital stock companies in the ranks of the legal reserve companies brings in an additional 111 observations (mostly stock companies). The major change relative to the results above (i.e., those obtained by running the models on the sample expanded by conversions only) is that the effects of financial requirements are mitigated by a modest degree. However, the estimates remain economically significant and meet the usual standards for statistical significance in all pooled specifications and in three of the four fixed effects specifications. 
Table I reports results from running the pooled logit model on the subsample of startups, as well as on the 1900-1924 and 1925-1949 subsamples. The results are qualitatively similar in most respects to those reported for the full sample. Results of fixed effects estimation are not reported, since so many observations are lost in the process of restricting the sample. For example, 299 of the 653 observations (30 states) are lost when using state fixed effects in the startup subsample, leaving 354 observations from 17 states. The results become very sensitive to specification changes in this setting: In particular, for the analogs to the specifications used in the main body of the paper, the financial requirement effects are evident (and significant) only when using the "Favor" variable.

\section{A.5.3 Analysis of Reorganizers and Converters}

As suggested by Table A, reorganizers were not a homogenous group. Limited capital stock and industrial companies chose the stock form almost exclusively when reorganizing as legal reserve companies (in fact, some of these companies did not actually reorganize - they simply "qualified" for the higher status and were so labelled by the state and rating agencies upon qualification). "Other reorganizers" (fraternals, assessment associations, mutual 
benefit associations, and so forth) chose the mutual form in some cases and the stock form in others; the same is true of "converters" (existing legal reserve companies that underwent conversion - either from stock to mutual or from mutual to stock). However, the patterns of form choice within these two subgroups were far different.

Table J shows pooled logit model results for the "other reorganizer" and "converter" subsamples, revealing opposite patterns with respect to the association of mutuality with financial requirements. The "other reorganizers" tended to mimic the startup tendency toward the path of least resistance, while the converters exhibited the exact opposite. The latter association may be evidence of firm organizers taking the easy route initially by forming a mutual, and later converting to stock after the enterprise had reached a critical mass: This stratagem seems likely to have been employed in Texas and Washington during the sample period.

We also gathered data on the assets and liabilities of the organizations prior to conversion (where it was available). ${ }^{\text {a }}$ The available data allowed us

\footnotetext{
${ }^{a}$ The main data sources were the state insurance department reports, and the data is incomplete. It was not always possible to locate the relevant department report, and, even when the report was available, the accounting data for the organization in question could still be incomplete (remember that many of these organizations had relaxed or non-existent reporting requirements).
} 
to classify ${ }^{\mathrm{b}}$ some of the 171 reorganizers according to whether or not their resources met the financial requirements of the domiciliary state at the date of their reorganization. The data indicate that "other reorganizers" inclined to the stock form when the reorganizer could not meet the financial requirements for either form, choosing the mutual form in only 8 of 37 such circumstances. However, the mutual form prevailed in 26 of 30 reorganizations where the reorganizer had resources sufficient to meet mutual requirements but not stock requirements. When the reorganizer had resources sufficient to choose either form, the mutual form was chosen in 37 of 55 cases. The remaining reorganizers could not be classified due to missing data.

These patterns suggest that reorganizers were influenced by financial requirements and also support the conjecture offered in the main body of the paper - that the greater financial resources of reorganizers may have allowed them the luxury of choosing the mutual form with greater frequency than

\footnotetext{
${ }^{\mathrm{b}}$ The classification algorithm proceeded as follows. Financial resources in the year prior to conversion were compared to the state's financial requirements in the year of reorganization, with the firm classified as having sufficient resources to meet a requirement (or not) on the basis of the comparison. If the prior year data was unavailable, resources in the year of conversion were used as a substitute if the firm had reorganized as a mutual (and thus was unlikely to have raised outside capital). Had prior year resources been the sole means of classification, the breakdown would have been: 7 mutuals out of 36 reincorporations where neither requirement could be met, 10 out of 14 where the mutual requirement could be met but the stock requirement could not, and 18 out of 40 where neither requirement was binding.
} 
startups.

\section{A.5.4 Analysis of Entry}

It is possible that financial requirements and other regulations acted as barriers to entry. While full examination of this possibility lies beyond the scope of this paper, we report here the association between company formations (based on data in the main sample) and the corresponding regulation data. As noted above, there are some gaps in our data on regulations and financial requirements - mostly in state-years where there were no formations. Nevertheless, we are able to create an unbalanced panel data set of formations by year by state, with valid observations in 2291 of the 2450 possible cells $(2450=49$ states times 50 years $)$.

Poisson regression models are used measure the association between regulation and entry (startups and reorganizations, but not conversions) of legal reserve companies. Table $\mathrm{K}$ shows the results of pooled and fixed effects Poisson regressions (see Wooldridge [12], pp. 668-78 for discussion of both models in the context of panel data). The fixed effects specifications reflect state effects. State population was used as the exposure variable in two of the specifications; census data offers decadal population estimates by state,

xxix 
and linear interpolation is used to fill in the intervening years.

Mutual financial requirements exhibited negative and statistically significant association with entry, while stock requirements did not. Since mutual requirements were typically the lower of the two requirements, this finding is consistent with financial requirements being barriers to entry. Other regulations did not exhibit a consistent and statistically robust association with entry. Entry dropped off significantly during the 1930's.

\section{References}

[1] American Council of Life Insurance (various years), Life Insurance Fact Book, Washington, D.C.: ACLI.

[2] A.M. Best Company (various years), Best's Insurance Reports - Life, Morristown and Oldwick: A.M. Best Company.

[3] Carter, W.M. (1977), "Capital and Surplus Accounts," in Life Insurance Accounting Strain, R. (ed.), Santa Monica: IASA.

[4] Kip, R.D.R. (1953), Fraternal Life Insurance in America Philadelphia: College Offset Press.

[5] Knight, C.K. (1920), The History of Life Insurance in the United States to $18 \% 0$, doctoral thesis, University of Pennsylvania.

[6] McCandless III, B. (2003) "You Can Take That, Or Worse: A Brief History of the Texas Department of Insurance: Part II: 1945 to the Present" Journal of Texas Insurance Law 3(1), 32-40.

[7] NAIC (various years), NAIC Compendium of State Laws on Insurance Topics, Kansas City: NAIC.

[8] Spectator Company (1911), Life Insurance History: 1843-1910 New York and Chicago: Spectator Company.

$\operatorname{xxx}$ 
[9] Spectator Company (various years), Insurance Year Book: Life New York, Chicago, and Philadelphia: Spectator Company and Chilton Company.

[10] Stalson, J.O. (1969), Marketing Life Insurance: Its History in America Homewood: Richard D. Irwin, Inc.

[11] U.S. Bureau of the Census (1975), Historical Statistics of the United States, Colonial Times to 1970, Washington, D.C.

[12] Wooldridge, J.M. (2002), Econometric Analysis of Cross Section and Panel Data, Cambridge (MA) and London: MIT Press.

$\mathrm{xxxi}$ 


\begin{tabular}{|l|c|c|c|}
\hline \multicolumn{4}{|c|}{ Table A - Breakdown of Full Sample (All Observations Collected) } \\
\hline & Stock & Mutual & Total \\
\hline $\begin{array}{l}\text { Startups } \\
\text { Legal Reserve }\end{array}$ & 526 & 127 & 653 \\
Limited Life \& Industrial* & $105^{*}$ & $6^{*}$ & $111^{*}$ \\
Reorganizers & 56 & 1 & 57 \\
Limited Life \& Industrial & 93 & 78 & 171 \\
Other & $47^{*}$ & $22^{*}$ & $69^{*}$ \\
Legal Reserve (conversions) & & & \\
\hline $\begin{array}{l}\text { Motes: Table includes all companies collected from the life insurance reports of Spectator } \\
\text { and Best's for the sample period. Asterisk indicates omission from the main sample. Form }\end{array}$ \\
listed under "Reorganizers" is the form prior to reorganization.
\end{tabular}

\begin{tabular}{|l|c|c|c|c|c|c|c|c|c|c|c|}
\hline \multicolumn{10}{|c|}{ Table B - Adoption Timeline for Laws } \\
\hline \hline & $\mathbf{1 9 0 0}$ & $\mathbf{1 9 0 5}$ & $\mathbf{1 9 1 0}$ & $\mathbf{1 9 1 5}$ & $\mathbf{1 9 2 0}$ & $\mathbf{1 9 2 5}$ & $\mathbf{1 9 3 0}$ & $\mathbf{1 9 3 5}$ & $\mathbf{1 9 4 0}$ & $\mathbf{1 9 4 5}$ & $\mathbf{1 9 5 0}$ \\
Annual Statement (AS) & $86 \%$ & $92 \%$ & $96 \%$ & $98 \%$ & $98 \%$ & $98 \%$ & $98 \%$ & $98 \%$ & $98 \%$ & $98 \%$ & $100 \%$ \\
Valuation (VAL) & $61 \%$ & $63 \%$ & $78 \%$ & $84 \%$ & $84 \%$ & $86 \%$ & $90 \%$ & $92 \%$ & $92 \%$ & $96 \%$ & $96 \%$ \\
Examination (EXM) & $84 \%$ & $86 \%$ & $94 \%$ & $96 \%$ & $96 \%$ & $96 \%$ & $98 \%$ & $100 \%$ & $100 \%$ & $100 \%$ & $100 \%$ \\
Voucher (VCH) & $0 \%$ & $0 \%$ & $37 \%$ & $45 \%$ & $47 \%$ & $49 \%$ & $51 \%$ & $53 \%$ & $55 \%$ & $55 \%$ & $53 \%$ \\
Valuation Deposit (VD) & $8 \%$ & $8 \%$ & $12 \%$ & $18 \%$ & $18 \%$ & $18 \%$ & $18 \%$ & $18 \%$ & $16 \%$ & $16 \%$ & $16 \%$ \\
Review (REV) & $2 \%$ & $4 \%$ & $41 \%$ & $47 \%$ & $49 \%$ & $53 \%$ & $53 \%$ & $61 \%$ & $63 \%$ & $65 \%$ & $69 \%$ \\
Rebates (RBT) & $51 \%$ & $55 \%$ & $86 \%$ & $90 \%$ & $94 \%$ & $94 \%$ & $94 \%$ & $96 \%$ & $96 \%$ & $98 \%$ & $98 \%$ \\
Incontestability (ICN) & $10 \%$ & $10 \%$ & $39 \%$ & $47 \%$ & $51 \%$ & $55 \%$ & $59 \%$ & $63 \%$ & $63 \%$ & $63 \%$ & $65 \%$ \\
Nonforfeiture (NON) & $22 \%$ & $22 \%$ & $55 \%$ & $59 \%$ & $61 \%$ & $63 \%$ & $65 \%$ & $69 \%$ & $71 \%$ & $76 \%$ & $84 \%$ \\
Investments (INV) & $57 \%$ & $59 \%$ & $76 \%$ & $82 \%$ & $84 \%$ & $86 \%$ & $86 \%$ & $90 \%$ & $90 \%$ & $92 \%$ & $92 \%$ \\
Dividend (DIV) & $51 \%$ & $55 \%$ & $59 \%$ & $61 \%$ & $63 \%$ & $65 \%$ & $67 \%$ & $69 \%$ & $69 \%$ & $71 \%$ & $71 \%$ \\
Political (POL) & $0 \%$ & $0 \%$ & $24 \%$ & $27 \%$ & $27 \%$ & $27 \%$ & $27 \%$ & $29 \%$ & $31 \%$ & $31 \%$ & $31 \%$ \\
Self-Dealing (SD) & $18 \%$ & $20 \%$ & $29 \%$ & $37 \%$ & $39 \%$ & $39 \%$ & $43 \%$ & $51 \%$ & $53 \%$ & $55 \%$ & $61 \%$ \\
Compensation (CMP) & $2 \%$ & $2 \%$ & $20 \%$ & $27 \%$ & $29 \%$ & $29 \%$ & $29 \%$ & $29 \%$ & $29 \%$ & $31 \%$ & $35 \%$ \\
Other Expense (OTH) & 0 & $0 \%$ & $6 \%$ & $6 \%$ & $6 \%$ & $6 \%$ & $6 \%$ & $6 \%$ & $8 \%$ & $8 \%$ & $8 \%$ \\
Board (BOD) & $2 \%$ & $2 \%$ & $45 \%$ & $51 \%$ & $55 \%$ & $55 \%$ & $55 \%$ & $61 \%$ & $61 \%$ & $65 \%$ & $69 \%$ \\
\hline Notes: Table shows the fraction of U.S. mainland jurisdictions & (48 states plus the District of Columbia) with \\
each law in place at each given date. See Table 1 for descriptions of the laws. & & & \\
\hline
\end{tabular}

\begin{tabular}{|c|c|c|c|c|c|c|c|c|c|c|c|c|c|c|c|c|}
\hline \multicolumn{17}{|c|}{ Table C - Correlation Matrix of Laws (Main Sample - 881 Observations) } \\
\hline & AS & VAL & EXM & $\mathrm{VCH}$ & VD & REV & RBT & ICN & NON & INV & DIV & POL & SD & CMP & OTH & BOD \\
\hline AS & 1.00 & - & - & - & - & - & - & - & - & - & - & - & - & - & - & - \\
\hline VAL & 0.44 & 1.00 & - & - & - & - & - & - & - & - & - & - & - & - & - & - \\
\hline EXM & 0.20 & 0.46 & 1.00 & - & - & - & - & - & - & - & - & - & - & - & - & - \\
\hline VCH & 0.13 & 0.20 & 0.13 & 1.00 & - & - & - & - & - & - & - & - & - & - & - & - \\
\hline VD & -0.12 & 0.05 & 0.07 & -0.04 & 1.00 & - & - & - & - & - & - & - & - & - & - & - \\
\hline REV & 0.16 & 0.25 & 0.17 & 0.71 & -0.14 & 1.00 & - & - & - & - & - & - & - & - & - & - \\
\hline RBT & 0.07 & 0.20 & 0.28 & 0.35 & -0.23 & 0.45 & 1.00 & - & - & - & - & - & - & - & - & - \\
\hline ICN & -0.09 & 0.11 & 0.11 & 0.61 & -0.24 & 0.66 & 0.40 & 1.00 & - & - & - & - & - & - & - & - \\
\hline NON & 0.16 & 0.28 & 0.17 & 0.56 & -0.29 & 0.57 & 0.39 & 0.61 & 1.00 & - & - & - & - & - & - & - \\
\hline INV & 0.28 & 0.55 & 0.32 & 0.37 & 0.12 & 0.42 & 0.13 & 0.16 & 0.46 & 1.00 & - & - & - & - & - & - \\
\hline DIV & 0.21 & 0.23 & 0.20 & 0.20 & -0.50 & 0.28 & 0.25 & 0.34 & 0.34 & 0.24 & 1.00 & - & - & - & - & - \\
\hline POL & 0.06 & 0.00 & 0.06 & 0.36 & -0.14 & 0.26 & 0.16 & 0.26 & 0.29 & 0.15 & 0.10 & 1.00 & - & - & - & - \\
\hline SD & 0.11 & 0.25 & 0.15 & 0.51 & 0.00 & 0.40 & 0.18 & 0.20 & 0.35 & 0.37 & 0.05 & 0.04 & 1.00 & - & - & - \\
\hline CMP & 0.11 & 0.16 & 0.11 & 0.43 & -0.36 & 0.53 & 0.32 & 0.57 & 0.58 & 0.30 & 0.29 & 0.01 & 0.34 & 1.00 & - & - \\
\hline OTH & 0.03 & 0.07 & 0.03 & 0.20 & -0.11 & 0.16 & 0.10 & 0.16 & 0.17 & 0.10 & -0.13 & 0.32 & 0.20 & 0.20 & 1.00 & - \\
\hline BOD & 0.15 & 0.24 & 0.15 & 0.55 & -0.30 & 0.57 & 0.39 & 0.54 & 0.68 & 0.42 & 0.45 & 0.37 & 0.43 & 0.69 & 0.23 & 1.00 \\
\hline
\end{tabular}




\begin{tabular}{|c|c|c|c|c|c|c|}
\hline \multirow[t]{2}{*}{ State } & \multicolumn{3}{|c|}{$\begin{array}{c}\text { Without Favoritism } \\
\text { (Mutual Requirement }>=\text { Stock Requirement) }\end{array}$} & \multicolumn{3}{|c|}{$\begin{array}{c}\text { With Favoritism } \\
\text { (Mutual Requirement }<\text { Stock Requirement) }\end{array}$} \\
\hline & Stock & Mutual & Total & Stock & Mutual & Total \\
\hline Arizona & 1 & 0 & 1 & 6 & 1 & 7 \\
\hline Colorado & 17 & 0 & 17 & 2 & 0 & 2 \\
\hline D.C. & 5 & 1 & 6 & 3 & 2 & 5 \\
\hline Idaho & 1 & 0 & 1 & 1 & 1 & 2 \\
\hline Louisiana & 11 & 1 & 12 & 2 & 0 & 2 \\
\hline Mississippi & 4 & 0 & 4 & 6 & 1 & 7 \\
\hline North Carolina & 1 & 1 & 2 & 17 & 8 & 25 \\
\hline New Mexico & 5 & 0 & 5 & 1 & 0 & 1 \\
\hline Nevada & 2 & 0 & 2 & 2 & 0 & 2 \\
\hline New York & 7 & 1 & 8 & 13 & 4 & 17 \\
\hline South Carolina & 8 & 0 & 8 & 8 & 1 & 9 \\
\hline Tennessee & 13 & 0 & 13 & 2 & 0 & 2 \\
\hline Texas & 18 & 0 & 18 & 70 & 43 & 113 \\
\hline Utah & 1 & 0 & 1 & 3 & 1 & 4 \\
\hline Virginia & 6 & 0 & 6 & 7 & 0 & 7 \\
\hline Washington & 12 & 1 & 13 & 4 & 6 & 10 \\
\hline Wyoming & 0 & 1 & 1 & 1 & 0 & 1 \\
\hline Total excl. Texas & 94 & 6 & 100 & 78 & 25 & 103 \\
\hline Grand Total & 112 & 6 & 118 & 148 & 68 & 216 \\
\hline
\end{tabular}

\begin{tabular}{|l|l|c|c|c|c|}
\hline \multicolumn{5}{|c|}{ Table E - Sample Statistics for Additional Variables } \\
(Supplement to Tables 1 and 4)
\end{tabular}




\begin{tabular}{|c|c|c|c|c|c|c|c|c|}
\hline \multirow{2}{*}{\multicolumn{5}{|c|}{\begin{tabular}{|l|r|}
\multicolumn{2}{|c}{ Table F - Regression Results for Logit Mod } \\
\\
& (Using Alternative Measure \\
Mooled Logit Model \\
\end{tabular}}} & \multicolumn{4}{|c|}{$\begin{array}{l}\text { rganizational Form Choice } \\
\text { ulation) }\end{array}$} \\
\hline & & & & & & ed Effec & Logit Mc & \\
\hline Mutual Requirement (MR) & $\begin{array}{l}-2.22^{\star \star} \\
(0.38)\end{array}$ & $\begin{array}{l}-2.06^{\star \star} \\
(0.40)\end{array}$ & - & - & $\begin{array}{l}-1.17^{\star \star} \\
(0.52)\end{array}$ & $\begin{array}{l}-0.83^{\star} \\
(0.49)\end{array}$ & - & - \\
\hline Stock Requirement (SR) & $\begin{array}{l}\mathbf{0 . 9 1} \\
(0.26)\end{array}$ & $\begin{array}{l}0.83^{\star \star} \\
(0.19)\end{array}$ & - & - & $\begin{array}{c}0.32 \\
(0.27)\end{array}$ & $\begin{array}{c}0.23 \\
(0.26)\end{array}$ & - & - \\
\hline Favor & - & - & $\begin{array}{l}3.34^{\star \star} \\
(0.45)\end{array}$ & $\begin{array}{l}3.16^{\star \star} \\
(0.46)\end{array}$ & - & - & $\begin{array}{l}2.15^{\star \star} \\
(0.64)\end{array}$ & $\begin{array}{l}1.48^{\text {** }} \\
(0.56)\end{array}$ \\
\hline Armstrong & $\begin{array}{c}0.63 \\
(0.44)\end{array}$ & - & $\begin{array}{c}0.56 \\
(0.41)\end{array}$ & - & $\begin{array}{c}0.85 \\
(0.57)\end{array}$ & - & $\begin{array}{c}0.80 \\
(0.57)\end{array}$ & - \\
\hline Basic Oversight (BO) & - & $\begin{array}{l}1.62^{\star \star x} \\
(0.65)\end{array}$ & - & $\begin{array}{l}1.48^{\star *} \\
(0.64)\end{array}$ & - & $\begin{array}{c}0.98 \\
(0.72)\end{array}$ & - & $\begin{array}{c}1.04 \\
(0.92)\end{array}$ \\
\hline Policy Oversight (PO) & - & $\begin{array}{c}0.00 \\
(0.51)\end{array}$ & - & $\begin{array}{l}-0.13 \\
(0.51)\end{array}$ & - & $\begin{array}{l}-0.42 \\
(0.54)\end{array}$ & - & $\begin{array}{l}-0.45 \\
(0.53)\end{array}$ \\
\hline Management Oversight (MO) & - & $\begin{array}{l}0.42 \\
(0.54)\end{array}$ & - & $\begin{array}{l}0.51 \\
(0.54)\end{array}$ & - & $\begin{array}{l}2.19^{\star \star *} \\
(0.90)\end{array}$ & - & $\begin{array}{l}2.19^{* *} \\
(1.00)\end{array}$ \\
\hline Fraternal & $\begin{array}{c}0.69 \\
(0.47)\end{array}$ & $\begin{array}{l}0.65^{\star} \\
(0.36)\end{array}$ & $\begin{array}{c}0.33 \\
(0.44)\end{array}$ & $\begin{array}{c}0.34 \\
(0.35)\end{array}$ & $\begin{array}{c}0.80 \\
(0.59)\end{array}$ & $\begin{array}{c}0.79 \\
(0.48)\end{array}$ & $\begin{array}{c}0.55 \\
(0.54)\end{array}$ & $\begin{array}{c}0.59 \\
(0.43)\end{array}$ \\
\hline Reorganization (RD) & $\begin{array}{c}1.05 \\
(0.76)\end{array}$ & $\begin{array}{c}1.36 \\
(1.27)\end{array}$ & $\begin{array}{l}3.87^{\text {xa }} \\
(0.67)\end{array}$ & $\begin{array}{l}3.97^{\text {x* }} \\
(1.04)\end{array}$ & $\begin{array}{c}1.62^{\star} \\
(0.85)\end{array}$ & $\begin{array}{l}2.16^{*} \\
(1.25)\end{array}$ & $\begin{array}{l}4.30^{\text {.* }} \\
(0.98)\end{array}$ & $\begin{array}{l}4.69^{\star \star} \\
(1.75)\end{array}$ \\
\hline $\mathrm{RD} * \mathrm{MR}$ & $\begin{array}{l}1.33^{\star \star} \\
(0.61)\end{array}$ & $\begin{array}{l}1.23^{\star \star} \\
(0.58)\end{array}$ & - & - & $\begin{array}{l}1.53^{\star \star} \\
(0.73)\end{array}$ & $\begin{array}{l}1.40^{\star *} \\
(0.69)\end{array}$ & - & - \\
\hline $\mathrm{RD} \mathrm{D}^{*} \mathrm{SR}$ & $\begin{array}{c}0.41 \\
(0.46)\end{array}$ & $\begin{array}{l}0.47 \\
(0.48)\end{array}$ & - & - & $\begin{array}{c}0.13 \\
(0.49)\end{array}$ & $\begin{array}{c}0.08 \\
(0.53)\end{array}$ & - & - \\
\hline RD*Favor & - & - & 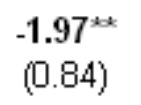 & $\begin{array}{c}-1.79^{\star x} \\
(0.78)\end{array}$ & - & - & $\begin{array}{l}-2.16^{\star *} \\
(0.99)\end{array}$ & $\begin{array}{l}-2.04^{\star *} \\
(0.97)\end{array}$ \\
\hline RD*Armstrong & $\begin{array}{l}-0.63 \\
(0.61)\end{array}$ & - & $\begin{array}{l}-0.65 \\
(0.65)\end{array}$ & - & $\begin{array}{l}-0.81 \\
(0.80)\end{array}$ & - & $\begin{array}{l}-0.84 \\
(0.87)\end{array}$ & - \\
\hline $\mathrm{RD}^{*} \mathrm{BO}$ & - & $\begin{array}{l}-0.52 \\
(1.07)\end{array}$ & - & $\begin{array}{l}-0.12 \\
(0.91)\end{array}$ & - & $\begin{array}{l}-0.19 \\
(1.12)\end{array}$ & - & $\begin{array}{c}-0.24 \\
(1.22)\end{array}$ \\
\hline $\mathrm{RD}^{*} \mathrm{PO}$ & - & $\begin{array}{l}-0.02 \\
(0.80)\end{array}$ & - & $\begin{array}{l}-0.18 \\
(0.78)\end{array}$ & - & $\begin{array}{c}0.46 \\
(0.95)\end{array}$ & - & $\begin{array}{c}0.35 \\
(0.90)\end{array}$ \\
\hline $\mathrm{RO} * \mathrm{MO}$ & - & $\begin{array}{l}-0.69 \\
(1.15)\end{array}$ & - & $\begin{array}{l}-0.82 \\
(1.18)\end{array}$ & - & $\begin{array}{l}-1.62 \\
(1.15)\end{array}$ & - & $\begin{array}{l}-1.60 \\
(1.26)\end{array}$ \\
\hline $\mathrm{RD}^{*}$ Fraternal & $\begin{array}{l}-1.11 \\
(0.72)\end{array}$ & $\begin{array}{l}-1.11^{*} \\
(0.64)\end{array}$ & $\begin{array}{l}-1.18 \\
(0.73)\end{array}$ & $\begin{array}{c}-1.30^{\star x} \\
(0.65)\end{array}$ & $\begin{array}{l}-1.22 \\
0.82\end{array}$ & $\begin{array}{c}-1.60^{\star \star} \\
(0.76)\end{array}$ & $\begin{array}{l}-1.27 \\
(0.95)\end{array}$ & $\begin{array}{c}-1.63^{\star \star} \\
(0.81)\end{array}$ \\
\hline Real Interest Rate & $\begin{array}{l}\mathbf{0 . 0 4 ^ { \star * }} \\
(0.02)\end{array}$ & $\begin{array}{l}\mathbf{0 . 0 4} \\
(0.02)\end{array}$ & $\begin{array}{l}0.05^{\star \star \star} \\
(0.02)\end{array}$ & $\begin{array}{l}0.05^{\star \star x} \\
(0.02)\end{array}$ & 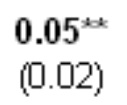 & $\begin{array}{l}\mathbf{0 . 0 5} \\
(0.02)\end{array}$ & $\begin{array}{l}\mathbf{0 . 0 6} \\
(0.02)\end{array}$ & $\begin{array}{l}0.05^{\star \star} \\
(0.02)\end{array}$ \\
\hline Constant & $\begin{array}{c}-2.60^{\text {s* }} \\
(0.47)\end{array}$ & $\begin{array}{l}-3.77^{\star \star} \\
(0.68)\end{array}$ & $\begin{array}{c}4.60^{\star \star} \\
(0.46)\end{array}$ & $\begin{array}{c}-5.59^{\star \star} \\
(0.85)\end{array}$ & - & - & - & - \\
\hline \begin{tabular}{|l|} 
Observations \\
Conversion factor
\end{tabular} & \multicolumn{4}{|c|}{881 (47 states) } & \multicolumn{4}{|c|}{750 (34 states) } \\
\hline \multicolumn{9}{|c|}{$\begin{array}{l}\text { Notes: Dependent variable is Mutual ( } 0 \text { if stock, } 1 \text { if mutual). Standard errors (in parentheses) are robust to } \\
\text { clustering by state. Statistical significance at } 10 \% \text { and } 5 \% \text { levels is denoted by * and } * \text {, respectively. Conversion } \\
\text { factor translates coefficients to marginal effects at the sample means. }\end{array}$} \\
\hline
\end{tabular}




\begin{tabular}{|c|c|c|c|c|}
\hline \multicolumn{5}{|c|}{$\begin{array}{c}\text { Table G - Regression Results for Pooled Logit Models of Form Choice } \\
\text { (Using Expanded Measures of Regulation) }\end{array}$} \\
\hline & \multicolumn{2}{|c|}{ Full Sample } & \multicolumn{2}{|c|}{ Startup Subsample } \\
\hline Mutual Requirement (MR) & $\begin{array}{l}-2.15^{\star \star} \\
(0.52)\end{array}$ & - & $\begin{array}{c}-1.87^{\star \star} \\
(0.42)\end{array}$ & - \\
\hline Stock Requirement (SR) & $\begin{array}{l}\mathbf{0 . 7 2} \\
(0.18)\end{array}$ & - & $\begin{array}{l}1.00^{2 k} \\
(0.30)\end{array}$ & - \\
\hline Favor & - & $\begin{array}{l}3.20^{2 *} \\
(0.56)\end{array}$ & - & $\begin{array}{l}3.13^{\star \star} \\
(0.55)\end{array}$ \\
\hline Basic Oversight (BO) & $\begin{array}{c}\mathbf{1 . 4 0}^{*} \\
(0.73)\end{array}$ & $\begin{array}{c}0.96 \\
(0.71)\end{array}$ & $\begin{array}{c}1.04 \\
(0.82)\end{array}$ & $\begin{array}{c}0.61 \\
(0.83)\end{array}$ \\
\hline Fraternal & $\begin{array}{c}0.65 \\
(0.49)\end{array}$ & $\begin{array}{c}0.32 \\
(0.45)\end{array}$ & $\begin{array}{c}0.85 \\
(0.53)\end{array}$ & $\begin{array}{c}0.46 \\
(0.44)\end{array}$ \\
\hline Reorganization (RD) & $\begin{array}{c}1.19 \\
(1.21)\end{array}$ & $\begin{array}{l}4.06^{\text {.x }} \\
(1.14)\end{array}$ & - & - \\
\hline $\mathrm{RD}+\mathrm{MR}$ & $\begin{array}{l}1.50^{\text {sk }} \\
(0.66)\end{array}$ & - & - & - \\
\hline $\mathrm{RD}^{*} \mathrm{SR}$ & $\begin{array}{c}0.42 \\
(0.43)\end{array}$ & - & - & - \\
\hline RD*Favor & - & $\begin{array}{l}-2.23^{\star \star} \\
(0.92)\end{array}$ & - & - \\
\hline $\mathrm{RD}^{*} \mathrm{BO}$ & $\begin{array}{l}-0.52 \\
(0.95)\end{array}$ & $\begin{array}{l}-0.19 \\
(0.87)\end{array}$ & - & - \\
\hline $\mathrm{RD}^{*}$ Fraternal & $\begin{array}{l}-1.27^{*} \\
(0.71)\end{array}$ & $\begin{array}{c}-1.43^{\star \star} \\
(0.72)\end{array}$ & - & - \\
\hline Valuation Deposit & $\begin{array}{c}0.18 \\
(0.46)\end{array}$ & $\begin{array}{c}0.47 \\
(0.50)\end{array}$ & $\begin{array}{c}0.71 \\
(0.63)\end{array}$ & $\begin{array}{c}1.00 \\
(0.63)\end{array}$ \\
\hline Voucher & -0.34 & $\begin{array}{l}-0.18 \\
(0.58)\end{array}$ & -0.90 & $\begin{array}{l}-0.87 \\
(0.73)\end{array}$ \\
\hline Review & $\begin{array}{l}\mathbf{0 . 7 1 ^ { \star }} \\
(0.36)\end{array}$ & 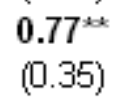 & $\begin{array}{l}1.14^{x} \\
(0.47)\end{array}$ & $\begin{array}{l}1.20^{2 \times} \\
(0.50)\end{array}$ \\
\hline Rebates & $\begin{array}{l}-0.44 \\
(0.45)\end{array}$ & $\begin{array}{l}-0.36 \\
(0.37)\end{array}$ & $\begin{array}{l}-0.27 \\
(0.62)\end{array}$ & $\begin{array}{l}-0.32 \\
(0.57)\end{array}$ \\
\hline Incontestability & $\begin{array}{c}0.43 \\
(0.41)\end{array}$ & $\begin{array}{l}-0.08 \\
(0.38)\end{array}$ & $\begin{array}{c}0.34 \\
(0.62)\end{array}$ & $\begin{array}{l}-0.08 \\
(0.66)\end{array}$ \\
\hline Nonforfeiture & $\begin{array}{l}-0.28 \\
(0.37)\end{array}$ & $\begin{array}{l}-0.17 \\
(0.35)\end{array}$ & $\begin{array}{l}-0.36 \\
(0.69)\end{array}$ & $\begin{array}{l}-0.11 \\
(0.66)\end{array}$ \\
\hline Dividend & $\begin{array}{c}0.13 \\
(0.49)\end{array}$ & $\begin{array}{c}0.42 \\
(0.56)\end{array}$ & $\begin{array}{c}0.43 \\
(0.69)\end{array}$ & $\begin{array}{c}0.73 \\
(0.69)\end{array}$ \\
\hline Political & $\begin{array}{c}0.60 \\
(0.50)\end{array}$ & $\begin{array}{l}\mathbf{1 . 0 1} \\
(0.47)\end{array}$ & $\begin{array}{c}0.34 \\
(0.64)\end{array}$ & $\begin{array}{c}0.91 \\
(0.60)\end{array}$ \\
\hline Self-Dealing & $\begin{array}{c}0.48 \\
(0.33)\end{array}$ & $\begin{array}{c}0.53 \\
(0.33)\end{array}$ & $\begin{array}{c}0.37 \\
(0.33)\end{array}$ & $\begin{array}{l}0.44 \\
0.37\end{array}$ \\
\hline Compensation & $\begin{array}{l}-0.09 \\
(0.47)\end{array}$ & $\begin{array}{c}0.05 \\
(0.41)\end{array}$ & $\begin{array}{c}0.73 \\
(0.66)\end{array}$ & $\begin{array}{c}0.97 \\
(0.62)\end{array}$ \\
\hline Other Expense & $\begin{array}{c}0.28 \\
(0.69)\end{array}$ & $\begin{array}{l}-0.12 \\
(0.56)\end{array}$ & $\begin{array}{l}-1.74^{\star} \\
(0.89)\end{array}$ & $\begin{array}{l}-1.82^{\star} \\
(0.93)\end{array}$ \\
\hline Board & $\begin{array}{l}-0.53 \\
(0.66)\end{array}$ & $\begin{array}{l}-0.53 \\
(0.67)\end{array}$ & $\begin{array}{l}-0.33 \\
(0.76)\end{array}$ & $\begin{array}{l}-0.45 \\
(0.80)\end{array}$ \\
\hline Real Interest Rate & $\begin{array}{l}\mathbf{0 . 0 5} \\
(0.02)\end{array}$ & $\begin{array}{l}\mathbf{0 . 0 6} \\
(0.02)\end{array}$ & $\begin{array}{l}\mathbf{0 . 0 5} \\
(0.02)\end{array}$ & $\begin{array}{l}\mathbf{0 . 0 6} \\
(0.02)\end{array}$ \\
\hline Constant & $\begin{array}{l}-3.44^{* *} \\
(0.71)\end{array}$ & $\begin{array}{l}-5.58^{\star \star} \\
(1.03)\end{array}$ & $\begin{array}{l}4.37^{\star \star} \\
(0.77)\end{array}$ & $\begin{array}{c}-5.92^{\star *} \\
(1.13)\end{array}$ \\
\hline Observations & 881 & es) & 653 & es) \\
\hline Conversion factor & 0.101 & 0.105 & 0.074 & 0.071 \\
\hline $\begin{array}{l}\text { Notes: Dependent variab } \\
\text { robust to clustering by st } \\
\text { respectively. Conversion }\end{array}$ & $\begin{array}{l}\text { (0 if sto } \\
\text { cal signi } \\
\text { ates coe }\end{array}$ & $\begin{array}{l}\text { tual). } 5 \\
10 \% \text { an } \\
\text { margin }\end{array}$ & $\begin{array}{l}\text { errors (in } \\
\text { els is de } \\
\text { at the s }\end{array}$ & $\begin{array}{l}\text { ses) are } \\
\text { t and } t \\
\text { eans. }\end{array}$ \\
\hline
\end{tabular}




\begin{tabular}{|c|c|c|c|c|}
\hline \multicolumn{5}{|c|}{$\begin{array}{r}\text { Table H - Regression Results for Logit Models of Organiz } \\
\text { (Using Capital Requirements instead of Asset Requi }\end{array}$} \\
\hline 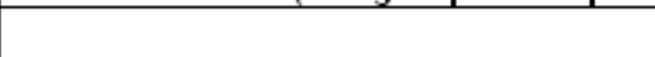 & & \multicolumn{2}{|c|}{ Fixed Effects Logit } \\
\hline Mutual Capital/Surplus Requirement (MC) & $\begin{array}{l}-2.17^{\star \star} \\
(0.51)\end{array}$ & $\begin{array}{l}-2.14^{\star \star} \\
(0.50)\end{array}$ & $\begin{array}{l}-0.76^{\star \star} \\
(0.38)\end{array}$ & $\begin{array}{l}-0.98^{\star \star} \\
(0.45)\end{array}$ \\
\hline Stock Capital/Surplus Requirement (SC) & $\begin{array}{l}1.00^{* *} \\
(0.24)\end{array}$ & $\begin{array}{l}0.97^{\star \star *} \\
(0.24)\end{array}$ & $\begin{array}{c}0.34 \\
(0.25)\end{array}$ & $\begin{array}{c}0.35 \\
(0.30)\end{array}$ \\
\hline MR minus MC & $\begin{array}{l}-1.96^{\star \star} \\
(0.43)\end{array}$ & $\begin{array}{l}-2.05^{\star \star} \\
(0.45)\end{array}$ & $\begin{array}{c}0.12 \\
(0.84)\end{array}$ & $\begin{array}{l}-0.29 \\
(0.90)\end{array}$ \\
\hline Regulate & $\begin{array}{l}0.54 \\
(0.34)\end{array}$ & $\begin{array}{l}\mathbf{0 . 6 3} \\
(0.32)\end{array}$ & $\begin{array}{l}\mathbf{1 . 8 1}^{*} \\
(1.00)\end{array}$ & $\begin{array}{l}1.88^{\star *} \\
(0.78)\end{array}$ \\
\hline Fraternal & $\begin{array}{c}0.48 \\
(0.41)\end{array}$ & $\begin{array}{l}0.77^{\star \star} \\
(0.39)\end{array}$ & $\begin{array}{l}0.47 \\
(0.53)\end{array}$ & $\begin{array}{l}1.06^{\star \star} \\
(0.49)\end{array}$ \\
\hline Reorganization (RD) & $\begin{array}{l}2.05^{\star \star} \\
(0.69)\end{array}$ & $\begin{array}{l}2.00^{2 \times} \\
(0.67)\end{array}$ & $\begin{array}{l}2.76^{\star *} \\
(0.72)\end{array}$ & $\begin{array}{l}2.49^{* *} \\
(0.75)\end{array}$ \\
\hline $\mathrm{RD}^{*} \mathrm{MC}$ & $\begin{array}{l}1.32^{* *} \\
(0.65)\end{array}$ & $\begin{array}{l}1.28^{* *} \\
(0.63)\end{array}$ & $\begin{array}{c}1.01 \\
(0.70)\end{array}$ & $\begin{array}{c}0.98 \\
(0.71)\end{array}$ \\
\hline $\mathrm{RD}^{*} \mathrm{SC}$ & $\begin{array}{l}-0.21 \\
(0.43)\end{array}$ & $\begin{array}{l}-0.21 \\
(0.41)\end{array}$ & $\begin{array}{l}-0.46 \\
(0.46)\end{array}$ & $\begin{array}{l}-0.34 \\
(0.47)\end{array}$ \\
\hline $\mathrm{RD}^{*}(\mathrm{MR}$ minus $\mathrm{MC})$ & $\begin{array}{l}1.71^{\star *} \\
(0.57)\end{array}$ & $\begin{array}{l}1.83^{\text {}} \\
(0.59)\end{array}$ & $\begin{array}{l}1.76^{\star \star} \\
(0.66)\end{array}$ & $\begin{array}{l}2.02^{* \star} \\
(0.78)\end{array}$ \\
\hline RD*Regulate & $\begin{array}{l}-0.72 \\
(0.90)\end{array}$ & $\begin{array}{l}-0.70 \\
(0.84)\end{array}$ & $\begin{array}{l}-1.63^{\star} \\
(0.99)\end{array}$ & $\begin{array}{l}-1.45 \\
(0.97)\end{array}$ \\
\hline RD*Fraternal & $\begin{array}{c}-1.53^{\star \star} \\
(0.52)\end{array}$ & $\begin{array}{c}-1.60^{* *} \\
(0.52)\end{array}$ & $\begin{array}{c}-1.37^{\star \star} \\
(0.61)\end{array}$ & $\begin{array}{c}-1.45^{\star \star} \\
(0.63)\end{array}$ \\
\hline $1910-1919$ & $\begin{array}{l}-0.94^{\star} \\
(0.43)\end{array}$ & - & $\begin{array}{l}-0.95^{\star} \\
(0.50)\end{array}$ & - \\
\hline $1920-1929$ & $\begin{array}{c}0.06 \\
(0.42)\end{array}$ & - & $\begin{array}{c}0.27 \\
(0.51)\end{array}$ & - \\
\hline $1930-1939$ & $\begin{array}{l}0.74^{\star} \\
(0.44)\end{array}$ & - & $\begin{array}{l}1.17^{\star \star} \\
(0.50)\end{array}$ & - \\
\hline $1940-1949$ & $\begin{array}{l}-0.23 \\
(0.49)\end{array}$ & - & $\begin{array}{c}0.09 \\
(0.58)\end{array}$ & - \\
\hline Real Interest Rate & - & $\begin{array}{l}\mathbf{0 . 0 4} \\
(0.02)\end{array}$ & - & $\begin{array}{l}\mathbf{0 . 0 5} \\
(0.02)\end{array}$ \\
\hline Constant & $\begin{array}{l}-2.33^{\star *} \\
(0.50)\end{array}$ & $\begin{array}{l}-2.57^{\star * *} \\
(0.48)\end{array}$ & - & - \\
\hline $\begin{array}{l}\text { Observations } \\
\text { Conversion factor }\end{array}$ & \multicolumn{2}{|c|}{881 (47 states) } & $\begin{array}{l}750 \\
-\end{array}$ & ates) \\
\hline $\begin{array}{l}\text { Motes: Dependent variable is Mutual (0 if } \\
\text { robust to clustering by state. Statistical } \\
\text { respectively. Conversion factor translates }\end{array}$ & $\begin{array}{l}1 \text { if mut } \\
\text { nce at } \\
\text { ients to }\end{array}$ & $\begin{array}{l}\text { tandard } \\
\text { d } 5 \% \text { le } \\
\text { al effect }\end{array}$ & $\begin{array}{l}\text { in pare } \\
\text { enote } \\
\text { samp }\end{array}$ & $\begin{array}{l}\text { s) are } \\
\text { and } t \\
\text { ns. }\end{array}$ \\
\hline
\end{tabular}




\begin{tabular}{|c|c|c|c|c|c|c|c|c|}
\hline \multicolumn{9}{|c|}{$\begin{array}{l}\text { Table I - Regression Results for Pooled Logit Models of Organizationa } \\
\text { (Analysis of Subsamples) }\end{array}$} \\
\hline & \multicolumn{4}{|c|}{ Startup (De Novo) Subsample } & \multicolumn{2}{|c|}{ 1900-24 Subsample } & \multicolumn{2}{|c|}{ 192549 Subsample } \\
\hline Mutual Requirement (MR) & $\begin{array}{l}-2.13^{\star \star} \\
(0.39)\end{array}$ & $\begin{array}{l}-2.12^{\star \star} \\
(0.38)\end{array}$ & - & - & $\begin{array}{c}-1.75^{\star \star} \\
(0.47)\end{array}$ & - & $\begin{array}{l}-2.73^{\star \star} \\
(0.58)\end{array}$ & - \\
\hline Stock Requirement (SR) & $\begin{array}{l}1.11^{* *} \\
(0.30)\end{array}$ & $\begin{array}{l}0.92^{\star \star} \\
(0.24)\end{array}$ & - & - & $\begin{array}{l}0.55^{\star} \\
(0.29)\end{array}$ & - & $\begin{array}{l}1.62^{* *} \\
(0.30)\end{array}$ & - \\
\hline Favor & - & - & $\begin{array}{l}3.22^{\star \star x} \\
(0.45)\end{array}$ & $\begin{array}{l}3.25^{\star \star x} \\
(0.45)\end{array}$ & - & $\begin{array}{l}3.73^{\star \star} \\
(0.80)\end{array}$ & - & $\begin{array}{l}2.94^{\star \star} \\
(0.53)\end{array}$ \\
\hline Regulate & $\begin{array}{c}0.48 \\
(0.33)\end{array}$ & $\begin{array}{r}0.62^{*} \\
(0.34)\end{array}$ & $\begin{array}{l}0.46 \\
(0.40)\end{array}$ & $\begin{array}{c}0.55 \\
(0.35)\end{array}$ & $\begin{array}{l}0.47 \\
(0.65)\end{array}$ & $\begin{array}{c}0.42 \\
(0.63)\end{array}$ & $\begin{array}{c}0.37 \\
(0.38)\end{array}$ & $\begin{array}{c}0.49 \\
(0.39)\end{array}$ \\
\hline Fraternal & $\begin{array}{c}0.52 \\
(0.41)\end{array}$ & $\begin{array}{l}0.81^{\star k} \\
(0.38)\end{array}$ & $\begin{array}{c}0.15 \\
(0.40)\end{array}$ & $\begin{array}{c}0.45 \\
(0.35)\end{array}$ & $\begin{array}{c}0.46 \\
(0.37)\end{array}$ & $\begin{array}{c}0.03 \\
(0.32)\end{array}$ & $\begin{array}{c}0.86 \\
(0.69)\end{array}$ & $\begin{array}{c}0.77 \\
(0.76)\end{array}$ \\
\hline Reorganization (RD) & - & - & - & - & $\begin{array}{l}1.23^{\star \star} \\
(0.61)\end{array}$ & $\begin{array}{l}3.92^{* \star} \\
(0.86)\end{array}$ & $\begin{array}{c}0.36 \\
(1.20)\end{array}$ & $\begin{array}{l}4.12^{\star *} \\
(1.24)\end{array}$ \\
\hline $\mathrm{RD}^{*} \mathrm{MR}$ & - & - & - & - & $\begin{array}{c}0.28 \\
(0.65)\end{array}$ & - & $\begin{array}{l}2.33^{\star \star} \\
(0.81)\end{array}$ & - \\
\hline $\mathrm{RD}^{*} \mathrm{SR}$ & - & - & - & - & $\begin{array}{l}0.85^{\star} \\
(0.47)\end{array}$ & - & $\begin{array}{l}0.67 \\
(0.87)\end{array}$ & - \\
\hline $\mathrm{RD}^{*}$ Favor & - & - & - & - & - & $\begin{array}{l}-1.71^{\star} \\
(1.00)\end{array}$ & - & $\begin{array}{l}-1.85^{*} \\
(1.05)\end{array}$ \\
\hline RD*Regulate & - & - & - & - & $\begin{array}{l}-3.14^{\star *} \\
(0.91)\end{array}$ & $\begin{array}{c}-2.60^{\text {** }} \\
(0.74)\end{array}$ & $\begin{array}{l}-0.30 \\
(1.08)\end{array}$ & $\begin{array}{c}-0.63 \\
(1.15)\end{array}$ \\
\hline $\mathrm{RD}^{*}$ Fraternal & - & - & - & - & $\begin{array}{l}-1.67^{\star \star} \\
(0.59)\end{array}$ & $\begin{array}{c}-1.35^{\text {„x }} \\
(0.61)\end{array}$ & $\begin{array}{l}-1.61 \\
(1.13)\end{array}$ & $\begin{array}{l}-1.93 \\
(1.30)\end{array}$ \\
\hline $1910-1919$ & $\begin{array}{l}-0.80 \\
(0.58)\end{array}$ & - & $\begin{array}{l}-0.82 \\
(0.52)\end{array}$ & - & - & - & - & - \\
\hline $1920-1929$ & $\begin{array}{c}0.56 \\
(0.58)\end{array}$ & - & $\begin{array}{c}0.20 \\
(0.52)\end{array}$ & - & - & - & - & - \\
\hline $1930-1939$ & $\begin{array}{c}0.90 \\
(0.58)\end{array}$ & - & $\begin{array}{l}\mathbf{0 . 9 3 ^ { \star }} \\
(0.56)\end{array}$ & - & - & - & - & - \\
\hline 1940-1949 & $\begin{array}{l}-0.40 \\
(0.76)\end{array}$ & - & $\begin{array}{l}-0.67 \\
(0.68)\end{array}$ & - & - & - & - & - \\
\hline Real Interest Rate & - & $\begin{array}{c}0.04 \\
(0.03)\end{array}$ & - & $\begin{array}{l}\mathbf{0 . 0 5 ^ { \star \star }} \\
(0.02)\end{array}$ & $\begin{array}{l}0.05^{\star} \\
(0.03)\end{array}$ & $\begin{array}{l}\mathbf{0 . 0 6} \\
(0.02)\end{array}$ & $\begin{array}{c}0.03 \\
(0.02)\end{array}$ & $\begin{array}{l}\mathbf{0 . 0 4 ^ { * }} \\
(0.02)\end{array}$ \\
\hline Constant & $\begin{array}{l}-2.69^{\star \star} \\
(0.62) \\
\end{array}$ & $\begin{array}{l}-2.56^{\star *} \\
(0.51)\end{array}$ & $\begin{array}{l}4.13^{\star \star} \\
(0.44)\end{array}$ & $\begin{array}{l}4.45^{\star \star} \\
(0.46)\end{array}$ & $\begin{array}{l}-2.06^{\star \star} \\
(0.57) \\
\end{array}$ & $\begin{array}{l}4.81^{\text {}} \\
(0.76)\end{array}$ & $\begin{array}{l}-3.06^{\text {** }} \\
(0.76) \\
\end{array}$ & $\begin{array}{l}4.27^{\star \star} \\
(0.82)\end{array}$ \\
\hline Observations & & $653(4$ & tates) & & $456(4$ & tates) & $425(4$ & tates) \\
\hline Conversion factor & 0.079 & 0.082 & 0.081 & 0.084 & 0.081 & 0.067 & 0.162 & 0.169 \\
\hline
\end{tabular}




\begin{tabular}{|c|c|c|c|c|}
\hline \multicolumn{5}{|c|}{$\begin{array}{c}\text { Table J - Regression Results for Pooled Logit Models of Form Choice } \\
\text { (Analysis of Reorganizer Subsamples) }\end{array}$} \\
\hline & \multicolumn{2}{|c|}{$\begin{array}{l}\text { "Other" Reorganizer } \\
\text { Subsample }\end{array}$} & \multicolumn{2}{|c|}{$\begin{array}{c}\text { Converter } \\
\text { Subsample }\end{array}$} \\
\hline Mutual Requirement (MR) & $\begin{array}{l}-1.08^{\star \star} \\
(0.23)\end{array}$ & - & $\begin{array}{l}1.82^{\star \star} \\
(0.64)\end{array}$ & - \\
\hline Stock Requirement (SR) & $\begin{array}{l}1.14^{\star *} \\
(0.26)\end{array}$ & - & $\begin{array}{c}-0.63 \\
(1.11)\end{array}$ & - \\
\hline Favor & - & $\begin{array}{l}1.96^{* *} \\
(0.32)\end{array}$ & - & $\begin{array}{l}-2.80^{\star *} \\
(0.88)\end{array}$ \\
\hline Regulate & $\begin{array}{l}0.87 \\
(0.69)\end{array}$ & $\begin{array}{c}0.69 \\
(0.64)\end{array}$ & $\begin{array}{c}0.56 \\
(0.87)\end{array}$ & $\begin{array}{c}1.13 \\
(1.02)\end{array}$ \\
\hline Fraternal & $\begin{array}{l}-0.08 \\
(0.45)\end{array}$ & $\begin{array}{l}-0.31 \\
(0.44)\end{array}$ & $\begin{array}{c}0.79 \\
(0.97)\end{array}$ & $\begin{array}{c}0.91 \\
(0.93)\end{array}$ \\
\hline Real Interest Rate & $\begin{array}{l}0.05^{*} \\
(0.03)\end{array}$ & $\begin{array}{l}\mathbf{0 . 0 6} \\
(0.03)\end{array}$ & $\begin{array}{l}-0.05 \\
(0.05)\end{array}$ & $\begin{array}{l}-0.05 \\
(0.04)\end{array}$ \\
\hline Constant & $\begin{array}{c}-1.04^{\star \star} \\
(0.47)\end{array}$ & $\begin{array}{c}-1.01^{\star \star} \\
(0.38)\end{array}$ & $\begin{array}{l}-1.96 \\
(1.84)\end{array}$ & $\begin{array}{l}-0.02 \\
(0.79)\end{array}$ \\
\hline Observations & \multicolumn{2}{|c|}{171 (38 states) } & \multicolumn{2}{|c|}{69 (24 states) } \\
\hline Conversion factor & 0.247 & 0.248 & 0.212 & 0.196 \\
\hline \multicolumn{5}{|c|}{$\begin{array}{l}\text { Notes: Dependent variable is Mutual (0 if stock, } 1 \text { if mutual). "Other" reorganizers are the original } \\
\text { reorganization subsample of } 228 \text { minus the } 57 \text { limited capital stock and industrial reorganizers. Converters } \\
\text { are legal reserve companies that mutualized or demutualized. Stardard errors robust to clustering by state are } \\
\text { shown in parentheses. Statistical significance at the } 10 \% \text { and } 5 \% \text { levels is indicated by *and } \text { ", respectively. } \\
\text { Conversion factor translates coefficients to marginal effects at the sample means. }\end{array}$} \\
\hline
\end{tabular}

Table K - Regression Results for Poisson Models of Company Formation

\begin{tabular}{|c|c|c|c|c|}
\hline & \multicolumn{2}{|c|}{$\begin{array}{l}\text { Pooled Poisson Model } \\
\text { (1) }\end{array}$} & \multicolumn{2}{|c|}{ Fixed Effects Poisson Model } \\
\hline Mutual Requirement (MR) & $\begin{array}{l}-0.18 \\
(0.12)\end{array}$ & $\begin{array}{l}-0.52^{\star *} \\
(0.13)\end{array}$ & $\begin{array}{l}-0.18^{\star \star} \\
(0.07)\end{array}$ & $\begin{array}{l}-0.15^{\star \star} \\
(0.07)\end{array}$ \\
\hline Stock Requirement (SR) & $\begin{array}{c}0.02 \\
(0.12)\end{array}$ & $\begin{array}{r}0.13 \\
(0.13)\end{array}$ & $\begin{array}{l}-0.11 \\
(0.09)\end{array}$ & $\begin{array}{l}-0.09 \\
(0.09)\end{array}$ \\
\hline Regulate & $\begin{array}{l}\mathbf{0 . 7 1 ^ { \star }} \\
(0.41)\end{array}$ & $\begin{array}{c}0.05 \\
(0.38)\end{array}$ & $\begin{array}{c}0.03 \\
(0.14)\end{array}$ & $\begin{array}{l}-0.02 \\
(0.14)\end{array}$ \\
\hline Fraternal & $\begin{array}{l}-0.12 \\
(0.32)\end{array}$ & $\begin{array}{l}-0.16 \\
(0.27)\end{array}$ & $\begin{array}{l}-0.09 \\
(0.12)\end{array}$ & $\begin{array}{l}-0.11 \\
(0.13)\end{array}$ \\
\hline $1910-1919$ & $\begin{array}{l}-0.40 \\
(0.28)\end{array}$ & $\begin{array}{l}-0.54^{* *} \\
(0.27)\end{array}$ & $\begin{array}{l}-0.36^{\star *} \\
(0.12)\end{array}$ & $\begin{array}{l}-0.49^{\star \star} \\
(0.12)\end{array}$ \\
\hline $1920-1929$ & $\begin{array}{l}-0.10 \\
(0.35)\end{array}$ & $\begin{array}{l}-0.43 \\
(0.31)\end{array}$ & $\begin{array}{l}-0.14 \\
(0.14)\end{array}$ & $\begin{array}{l}-0.37^{\star \star} \\
(0.14)\end{array}$ \\
\hline $1930-1939$ & $\begin{array}{l}-0.71^{\star \star} \\
(0.26)\end{array}$ & $\begin{array}{l}-1.04^{\star \star} \\
(0.28)\end{array}$ & $\begin{array}{l}-0.64^{\star *} \\
(0.15)\end{array}$ & $\begin{array}{l}-1.01^{\star \star} \\
(0.15)\end{array}$ \\
\hline $1940-1949$ & $\begin{array}{l}-0.44 \\
(0.32)\end{array}$ & $\begin{array}{l}-0.84^{\star *} \\
(0.32)\end{array}$ & $\begin{array}{l}-0.36^{\star \star} \\
(0.15)\end{array}$ & $\begin{array}{l}-0.83^{\star \star} \\
(0.15)\end{array}$ \\
\hline Constant & $\begin{array}{l}-0.58^{* \star} \\
(0.28)\end{array}$ & $\begin{array}{c}-14.64^{\star \star} \\
(0.29) \\
\end{array}$ & - & - \\
\hline $\begin{array}{l}\text { Exposure Variable } \\
\text { Observations }\end{array}$ & $\begin{array}{l}\text { No } \\
2291\end{array}$ & $\begin{array}{r}\text { Yes } \\
\text { lations) }\end{array}$ & $\begin{array}{l}\text { No } \\
2241\end{array}$ & $\begin{array}{l}\text { Yes } \\
\text { ions) }\end{array}$ \\
\hline $\begin{array}{l}\text { Notes: Dependent variabl } \\
\text { state and year. Standard } \\
\text { models. Statistical signifi } \\
\text { exposure variable in (2) an }\end{array}$ & $\begin{array}{l}\text { numbe } \\
10 \% \text { an in } \\
\text { stimate }\end{array}$ & $\begin{array}{l}\text { reserve for } \\
\text { ses and ar } \\
\text { els is indic } \\
\text { opulation. }\end{array}$ & $\begin{array}{l}\text { (excluding } \\
\text { to clusteri } \\
\mathrm{h}^{*} \text { and } \\
\text { (3) and (4) }\end{array}$ & $\begin{array}{l}\text { s) in the } \\
\text { in the po } \\
\text { The } \\
\text { e fixed } \mathrm{e}\end{array}$ \\
\hline
\end{tabular}

